\title{
The role of national governance systems in biofuel development A comparative analysis of lessons learned
}

George Schoneveld, Laura German, Renata Andrade, Melissa Chin, Wisnu Caroko and Omar Romero-Hernández

\section{Key points}

- Governments have played only a marginal role in the development of the biofuels market in most developing countries.

- For biofuel development to contribute to domestic energy security objectives, considerable initial financial support may be required.

- Biofuel production for domestic or underregulated export markets may contribute to environmental degradation, given the poor performance of feedstock cultivation in environmental impact assessments.

- Investment liberalisation and the lack of formal mechanisms to enhance smallholder participation indicate that benefits from biofuel development will likely be highly concentrated.

- The expansion of large-scale biofuel plantations could limit traditional land users' access to resources due to ineffective governance.

- Poor enforcement-rather than absenceof existing regulatory safeguards is one of the main constraints to sustainable biofuel development.

\section{Introduction}

The global production of biofuels has almost tripled since 2005. This rapid increase in production has been driven largely by policies in industrialised countries aiming to reduce both their dependency on imported fossil fuel products and carbon emissions (especially within the European Union). For many developing countries, this trend presents new trade opportunities, which they are well positioned to exploit given their potential competitiveness in the cultivation of biofuel feedstocks. As many developing countries are also especially vulnerable to oil price shocks, there is ample reason for their governments to explore means to enhance their domestic biofuel production capacity. However, this poses a number of governance challenges. This brief draws on a collection of case studies from emerging and developing economies (Brazil, Mexico, Indonesia, Malaysia, Zambia and Ghana) to identify some of these challenges. It first considers the role of government in developing a viable domestic biofuel industry and then explores the effectiveness of national governance systems in managing the potential externalities of biofuel sector development.

\section{Government role in market development}

\section{Experience in Brazil}

Brazil has one of the oldest and most competitive biofuel sectors. With sugarcane-derived ethanol production dating back to the mid 1970s, Brazil now accounts for almost one- 
third of total global production - making it the second largest biofuel producer in the world. Much of the initial government commitment to sector development stemmed from the need to reduce the country's exposure to high oil prices during the 1973 oil crisis. With a well-established sugarcane sector, which at that time was under pressure from low world sugar prices, diversification into ethanol production also created an opportune market outlet for sugarcane (Andrade and Miccolis in press).

The adoption of targeted incentive-based policies was instrumental in stimulating early sector development. For example, the Brazilian government imposed the phased implementation of mandatory blending requirements, which now stand at 20\% to 25\% ${ }^{1}$, and offered discounted prices for ethanol fuels at the pump. This created a guaranteed domestic market. In addition, ethanol producers were eligible for several other incentives, including concessionary credit lines, price and off-take guarantees and tax breaks. Moreover, research and development by public institutions was critical to sector innovation, especially with regard to agronomic and biotechnological improvements (Andrade and Micollis in press). Although the cost of production in the early stage of the programme exceeded the price of gasoline, technological advances and gains from economies of scale brought down the cost of production. With pure ethanol typically selling at between $60 \%$ and $70 \%$ of the price of gasoline, producer subsidies and pricing interventions are no longer necessary (Goldemberg et al. 2004).

\section{Experience in Malaysia and Indonesia}

Although Brazil has a long-established biofuel sector, in most other countries commitment to developing a domestic biofuel sector is more recent. The rise in oil prices between 2005 and 2008, in particular, put biofuels firmly on the political agenda in many countries. Both Malaysia and Indonesia, for instance, adopted biofuel policies and laws during this period. Like Brazil, both countries are well positioned to exploit a well-established feedstock sector-in this case oil palm — which at the time was also struggling with low market prices. Domestic consumption of biodiesel was seen as offering two key benefits: it would support the creation of another, more profitable, market for palm oil products, and it could contribute to alleviating the burgeoning federal cost of fuel subsidies. Both countries heavily subsidise the end-price of transportation fuels; they have sought to ease this burden through the blending of biofuels, particularly biodiesel (Chin in press; Caroko et al. in press). The effect of high oil prices was especially detrimental to Indonesia, which, in contrast to Malaysia, is now a net oil importer. When oil prices peaked in 2008, fuel subsidies in Indonesia constituted almost one-third of total government spending (Dillon et al. 2008). In response to these pressures, both countries announced ambitious blending targets and established dedicated government agencies to oversee development of the biofuel sector.

In response to this ostensible government commitment and renewed global interest in biofuels, many palm oil sector actors in both countries made considerable investments in their biodiesel production capacities. Total production capacity in 2010 was estimated at 2.6 billion L for Malaysia and almost 4 billion L for Indonesia (Adnan 2010; van Gelder et al. in press). Despite this early enthusiasm amongst both private and public sectors, current production remains well under installed capacities, with Malaysia producing only 222 million $L$ and Indonesia 104 million $L$ of biodiesel in 2009 (USDA 2010; Baskoro 2010). With recovering palm oil prices, decreasing world fossil fuel prices and the recent crunch in credit markets, it is more profitable for producers to sell crude palm oil (CPO) than biodiesel. Contrary to initial objectives, biodiesel has become a burden on state coffers as its viability vis-à-vis petro-diesel has diminished.

In Indonesia, the government has since introduced consumer subsidies over and above the existing fuel subsidy, and is providing various producer incentives to encourage domestic biodiesel production and prevent price inflation at the pump. Despite this support, the state-owned oil company remains reluctant to blend biodiesel, and producers are still insufficiently motivated to increase biodiesel production. As a result, mandatory blending requirements remain largely unmet. The Malaysian government has delayed the introduction of mandatory blending as it is unwilling to provide additional fuel subsidies and meet private sector demands for fiscal incentives (Chin, in press). Thus, as government support is inadequate to boost private sector investments, the biodiesel sector in both countries remains in limbo, with neither government able to meet original blending targets. This can be attributed to their reluctance to fully accommodate producers or to force oil marketing companies to blend at a loss.

\section{Experience in Mexico}

A similar shift in faith has been observed in Mexico. In 2008, as global oil prices soared, a dedicated biofuel law and strategy were adopted. The primary objective was to use sugarcane-based ethanol in place of the oxygenating agent methyl tertiary butyl ether (MTBE), which, in contrast to petroleum, Mexico largely imports (Schifter et al. 2010)².

\footnotetext{
1 Brazil's Ministry of Agriculture can change blending ratios to maintain a price balance between ethanol and sugar and respond to domestic supply fluctuations.

2 MTBE represents approximately $6 \%$ of Mexico's gasoline volume.
} 
However, just as Mexico was set to commence ethanol blending, the state oil company failed to source the required ethanol from domestic producers because it was unwilling to pay market price. The implementation of the first blending mandates is facing considerable delays and domestic production is failing to take off. Although the government is committed to incorporating biofuels in the country's energy mix, it has hesitated in transforming its vision into concrete actions (especially with regard to incentives) (Romero-Hernández et al. in press). In contrast to Malaysia and Indonesia, Mexican biofuel producers did not respond to improved export opportunities as they cannot compete with other ethanol-exporting countries (notably Brazil) (Cámara Nacional de las Industrias Azucarera y Alcoholera 2010).

\section{Experience in Zambia and Ghana}

In contrast to the countries discussed above, many developing countries, especially in Africa, have not yet passed far-reaching legislative provisions to open the way for the development of a domestic biofuel sector. For instance, in the land-locked and net oil-importing Zambia, the government has been in the process of developing a national biofuel policy for five years. The policy development is driven by the country's need to enhance its energy independence and to capitalise on new opportunities in the agriculture sector. However, it has not yet managed to formally enact a coherent policy or regulatory framework, in part due to ongoing disagreements between the government and producers. The government is unwilling to provide any commitments or incentives until the private sector has invested in the necessary production capacity to meet blending mandates. This creates challenges for domestic producers with limited capital, as off-take guarantees (e.g. through blending mandates) cannot be used as a form of collateral (German and Schoneveld in press). Nevertheless, investments continue. A number of largescale, mostly foreign, investors are developing large-scale jatropha plantations across the country, having collectively gained access to more than 600000 ha of land (German and Schoneveld in press). Many of these companies are targeting high returns on major export markets, notably the European Union, instead of the domestic market. Zambia is considered a competitive investment location because of its relative abundance of cheap, agroecologically suitable land and favourable investment conditions (e.g. concessionary tax rates, duty exemptions and unrestricted profit repatriation). Therefore, although both national and international market conditions are poor, anticipated long-term returns on the global market are continuing to drive these biofuel projects.

In Ghana, the situation is very similar. Biofuel investors have gained access to more than 1.1 million ha of land, mostly for jatropha cultivation, in the absence of any government incentives or regulations targeting biofuel development (Schoneveld and German in press). Although the government has formulated strategies and targets for the incorporation of biofuels into the energy mix, little progress has been made in implementing them. Although Ghana initially embraced biofuels as a means to enhance energy security, the recent discovery of substantial off-shore oil reserves means the country is poised to become a net oil exporter. As a result, the immediate imperative to develop biofuels domestically appears to have waned considerably. Biofuels are instead perceived as contributing to key government development objectives, such as agricultural modernisation and promotion of untraditional export products (i.e. other than cocoa and gold). Like Zambia, the impetus for sector development in Ghana is favourable generic investment conditions, such as access to land and fiscal incentives, and perceived long-term opportunities in export markets (Schoneveld and German in press). In both countries, however, most projects are still in the early stages, with both planted areas and biofuel production volumes remaining insignificant relative to land access.

\section{Comparing experiences}

Common to the cases of Indonesia, Ghana, Malaysia and Zambia is that the rapid initial investments in the sector were a function more of global market opportunities (stemming from high oil and low commodity prices) than of government intervention. However, if governments are to ensure that biofuel producers consistently produce quantities that are sufficient to meet domestic blending targets, they must make commitments even when biofuel production is not economically viable. This is particularly the case when feedstocks have multiple end uses (as in the case of sugarcane and oil palm). Otherwise, producers will tend to produce at any point in time for the market that is most profitable, which may lead to supply instability for biofuels. A similar situation arose in Brazil in the 1980s when high world sugar prices led to a rapid reduction in ethanol output. Only after the government implemented a new round of financial incentives did the sector recover. Thus, in cases where domestic biofuel blending as part of an energy security agenda is a key government objective for the sector, mechanisms must be in place to ensure stability of supply. This will incur additional costs, which the government can internalise and/or transfer to oil marketing companies and the final consumers. Considering the political bargaining power of oil marketing companies in many countries and the political sensitivity of higher prices at the pump, it is likely that governments will prefer to internalise these costs. Governments also need to ensure that price fluctuations on the energy, food and feed markets do not disrupt domestic production to the extent that it creates domestic supply deficits. The Brazilian experience with the ethanol sector is an important case in point. 
The cases of Indonesia, Malaysia and Mexico illustrate the reluctance of governments to bear the costs of developing a stable biofuel sector. These governments have been unwilling to transfer the costs of biofuel blending to their main oil distributers even though in all three countries these are state-owned monopolies. Thus, in the absence of economic imperative, governments may not have sufficient motivation to follow through on their original objectives and ensure that the interests of different stakeholders remain aligned. This is a key constraint to developing a competitive domestic biofuel sector and to reducing dependency on fossil fuels.

\section{Government role in enhancing sector sustainability}

The preceding discussion shows the complexity of developing a competitive national biofuel industry. Also important are the potential implications of advancing the sector. Growing global demand for biofuels raises various sustainability concerns. Large-scale monoculture plantations in particular could generate numerous adverse environmental (e.g. loss of biodiversity and forest cover, increased fire risk and localised pollution) and socioeconomic (e.g. involuntary resettlement, food insecurity and demographic shifts) impacts associated with such land use changes. A number of trade-relevant initiatives in particular have sought to minimise these potential impacts. These include feedstock-specific international certification systems (e.g. Roundtable for Sustainable Palm Oil, Roundtable on Sustainable Soy and the Better Sugar (ane Initiative), an international certification system applicable to all biofuels (e.g. Roundtable on Sustainable Biofuels) and governmentregulated sustainability standards (e.g. EU Renewable Energy Directive and US Renewable Fuel Standard 2). These systems, however, generally have implications only for producers in developing countries that depend on trade with OECD countries. Therefore, the producer countries themselves will need to regulate significant portions of biofuel consumption.

Sustainability issues specific to biofuels are acknowledged by governments in all the case study countries and are incorporated into policy and strategy documents in most of these countries. However, very few concrete legislative provisions have been enacted that seek to reduce the negative and enhance the positive impacts (e.g. employment generation and modernisation of the agriculture sector) of biofuel development. Those that have been ratified typically relate to politically sensitive issues. For example, in Mexico, maize, the most important staple crop, has been banned as a feedstock for ethanol. In a recent attempt by Brazil to develop its biodiesel sector, regulations were passed that provide biodiesel producers with additional fiscal incentives when they source a minimum percentage of feedstock from 'family farmers'. However, the bulk of feedstock was then purchased from well-established soya farmers rather than from farmers in the poorer northern regions, which largely undermined the original objective of these regulations (Andrade and Miccolis in press).

\section{Fostering smallholder participation}

The issue of smallholder participation in the development of the biofuel sector is an important policy concern in all case study countries. This is because of its relevance to broader rural development objectives. Numerous state governments in Mexico, for instance, have extended fiscal incentives and technical support to promote smallholder cultivation of jatropha on degraded lands. The governments of Indonesia, Ghana and Malaysia all set out to develop similar smallholder jatropha programmes, framed largely as poverty alleviation initiatives. Although the programme in Mexico has met with mixed success, most of these programmes have generally failed to take off. In practice, considerably more technical and financial support is needed for jatropha to produce commercially viable yields.

To date, governments have had little success in stimulating business models for biofuels that incorporate smallholders. In Ghana, for instance, the biofuel sector is dominated entirely by large-scale vertically integrated companies (Schoneveld and German in press). Similarly, with increasing competition and deregulation, the Brazilian ethanol sector is increasingly concentrated, with smallholders now producing less than 15\% of sugarcane for ethanol (Abramovay 2008). Despite strong smallholder participation during the early days of sector development in Zambia, large-scale private sector actors are increasingly dominating the biofuel value chain.

Large-scale private sector actors also control biodiesel production and distribution in Indonesia and Malaysia. Historically, however, smallholders have figured prominently in upstream activities, and now contribute $35-40 \%$ of total oil palm fruit yields (Sheil et al. 2009). Concerted efforts by both governments over decades (in the case of Malaysia, dating back to the 1950s) to support smallholder production capacity and enhance mutually beneficial linkages with large-scale enterprise have been instrumental in leveraging greater societal benefits from oil palm development.

A key underlying issue in places where biofuel development has not been (or is unlikely to be) inclusive of smallholders is the lack of formal mechanisms to encourage large-scale producers to engage smallholders. It appears that such engagement does not occur in the biofuel sector without government intervention. This can be attributed to issues related to economies of scale, transaction costs, relative 
risk propensities, barriers to technological uptake and end-market concentration. Hence, the market may not be the ideal vehicle for inclusive agricultural development, and extensive government support (technical, financial and regulatory) may be required to enhance the competitiveness of smallholder-oriented business models. In many countries, the lack of intervention can largely be attributed to government reluctance to over-regulate, and thus deter, large-scale investments. This attitude may stem from rather modernistic views on development (e.g. Ghana and Zambia) or be due to strong political lobbying from large-scale agribusiness (e.g. Brazil). Highly liberal investment policies undermine efforts not only to enhance smallholder participation in the market but also to effectively capture domestic economic and technological spillovers from large-scale (foreign) investments.

\section{Environmental protection}

National biofuel legislation in developing countries does not adequately account for potential negative externalities. Nevertheless, a broad array of extrasectoral legislation has a bearing on biofuel development, especially feedstock production. All countries have lands that are under strict protection and cannot be converted to agricultural land uses because of their ecological and/or cultural values. In Brazil in 2008, the government adopted agroecological zoning laws for sugarcane in order to protect ecologically significant biomes. This law effectively prohibits sugarcane cultivation in $92.5 \%$ of the national territory (Andrade and Miccolis in press). Malaysia has also recently announced a ban on forest clearing for oil palm, with expansion only permitted on land zoned as agricultural. As part of a bilateral agreement with Norway, the Indonesian government has announced a 2-year moratorium, beginning in 2011, on the conversion of natural forests and peatlands deeper than $3 \mathrm{~m}$.

Government initiatives have been introduced to reduce the environmental impacts of future feedstock expansion in response to longstanding disputes, especially between government and civil society, over the environmental footprints of these feedstocks. Oil palm, in particular, has been an important driver of deforestation, biodiversity loss and greenhouse gas emissions. For instance, in both Indonesia and Malaysia, an estimated $55-60 \%$ of oil palm expansion between 1990 and 2005 was at the expense of forests (Koh and Wilcove 2008). In Brazil, the interaction between pasture and soya expansion (now Brazil's primary biodiesel feedstock) is playing a key role in the expansion of the agricultural frontier into the Amazon Basin. Although the growth of the global biofuels market cannot be held responsible for these impacts, these experiences do illustrate the past ineffectiveness of national governance systems in regulating land use change for large-scale monoculture.
Although the framework environmental laws in the case study countries do have shortcomings, weak enforcement-rather than the absence_-of existing environmental regulations usually underlies this poor environmental performance.

In the Brazilian Amazon, for instance, rural properties are required to set aside $80 \%$ of their land area as 'legal reserves', in which the native vegetation must be preserved. However, due to a combination of capacity constraints, inadequate political will and remoteness, these regulations were in the past often not enforced or complied with (Andrade and Miccolis in press). In Indonesia, there are several instances of oil palm companies converting forests outside concession areas or before obtaining the necessary concession permits, without any legal repercussions (Caroko et al. in press).

In most countries, companies are required to conduct an environmental impact assessment (EIA) to obtain the necessary environmental permits. These assessments identify potential environmental and social impacts of land use change and determine whether and under what conditions projects should be carried out. On paper, procedures for conducting an EIA are typically elaborate and comprehensive. In practice, however, EIAs often do not serve their intended purpose. For example, most biofuel companies in Ghana were found to be operating without having conducted an EIA, despite it being mandatory for landholdings above a certain size. Relevant environmental agencies were in many cases found to be completely unaware of these developments. Even when ElAs are carried out, they are sometimes approved despite the risk of extensive adverse impacts (Schoneveld and German in press). In Zambia, for instance, companies were permitted to convert large areas of land, even though much remained under forest cover or, in one case, covered an important wetland area (German and Schoneveld in press).

In Indonesia and Malaysia as well problems are evident following EIA approval. For example, companies often do not comply with environmental management plans (developed to support the mitigation of impacts identified by the EIA) due to the lack of government capacity in monitoring and enforcement.

It is therefore questionable whether normative frameworks such as these are an effective tool for impact mitigation. To some extent, these weaknesses can be attributed to structural governance issues in many developing countries (e.g. related to capacity, resources, and accountability). However, they are also attributable to the entrenched belief amongst many government stakeholders that these types of commercial developments are justified for their positive contribution to 'development', regardless of their 
environmental or social consequences. This appears to be particularly true when such development contribute to national economic indices (balance of trade, revenue) or alleviate the fiscal burden of public service delivery. Hence, in many developing countries, governance challenges threaten to undermine initiatives to reduce the environmental impacts of biofuel feedstock cultivation (e.g. such as those now in Brazil, Indonesia and Malaysia), especially when these initiatives are in response to external (donor) or civil society pressures.

\section{Land tenure security}

The issue of land rights is an additional challenge in developing a smallholder-inclusive biofuel sector. Largescale biofuel feedstock plantations typically require large contiguous areas of land, and will in most situations conflict with established land uses and users. In all case study countries, large proportions of the total land area are under some form of communal or customary tenure. These traditional rights to land are supported in legislation, but in practice rarely provide full tenure security. Historically, oil palm expansion in Malaysia and Indonesia has often been at the expense of indigenous populations and the land uses on which they depend. Even in situations where communities are offered restitution for their loss of livelihoods, conflicts have frequently erupted or been brought to court over broken promises, breaches of contract or limited downward accountability of customary leaders (Caroko et al. in press). However, as land rights are often poorly documented, establishing legitimate claims is also difficult.

Numerous large-scale land transfers have been negotiated in Zambia and Ghana without any form of community participation, consent, and redress. Typically, local elites, such as traditional authorities, have the legal right to alienate customary land to investors without involving their constituents. Presented with an opportunity for personal gain, these local elites may not be compelled to act in the interest of their constituents, with land transfer agreements often shrouded in secrecy (German and Schoneveld in press; Schoneveld and German in press). Although judicial mechanisms for seeking recourse do exist, the transaction costs often put these out of reach for affected land users. Such land users generally lack the capacity to claim their rights, due to limited awareness, inability to navigate the overly complex institutional landscape and lack of resources. These land users are often reluctant to defy traditional authority or the intricacies of community relations, customs and histories. Moreover, most customary land users were found to be highly supportive of plantation development, with high expectations of 'development' and 'modernisation', thereby in many cases legitimising the actions of traditional authorities and curtailing possible public opposition (Schoneveld and German in press).
With restrictions on the alienation of customary land, problems related to land tenure insecurity are not evident in equal magnitude in Mexico and Brazil. Most land transfers are on a willing buyer-willing seller basis. Land transactions are typically voluntary, although in Brazil we see evidence of an increasing concentration of land with large-scale commercial agro-businesses, particularly foreign investors. To limit large-scale land ownership by non-Brazilians, the government prohibited foreigners from acquiring tracts larger than 5000 ha in August 2010 (Colitt and Ewing 2010). Although the land sector has become more deregulated in Mexico, restrictions are still placed on the size of large-scale industrial plantations and on foreign land ownership in general (Romero-Hernández et al. in press).

In the other case study countries, however, the expansion of large-scale biofuel feedstock plantations threatens to lead to increased concentration of landholdings amongst largely foreign companies at the expense of traditional land users. This process could severely undermine the effective internalisation and equitable distribution of the potential developmental benefits of biofuel development.

\section{Conclusions}

Research has shown that recent efforts by many governments to promote the consumption and production of biofuels have met with limited success. This can largely be attributed to unfavourable market conditions, complex political economic relations and the high costs of sector development. Despite the consequent stagnation in the expansion of biofuel production, producers appear highly responsive to global market conditions (e.g. export opportunities). When biofuel production becomes financially viable_-for example, with higher oil prices or lower prices for other feedstock products, or as more biofuel blending is mandated - the sector will likely revitalise rapidly.

Although this potential future expansion could generate various economic benefits related to import substitution and increased export earnings, negative externalities could result. Many, particularly developing, countries have not adopted biofuels-specific sustainability regulations and lack the legal and institutional frameworks to effectively mitigate the negative impacts and capture the positive impacts of sector development. Poor track records in regulatory implementation and enforcement are of particular concern. Thus, many current national governance systems are ill equipped to deal effectively with biofuel development. As a result, sector expansion could lead to a concentration of economic gains, environmental destruction and displacement of important agricultural and forested land uses. Since international initiatives seeking to regulate these potential impacts capture only a small proportion of the 
biofuels market, it is especially critical that producer countries increase their capacity and political will to effectively manage the many facets of biofuel development.

\section{Acknowledgements}

This brief is based on six individual case study reports whose lead authors of these reports have been acknowledged as co-authors of this brief. We therefore extend our gratitude to the other authors of the reports: Miriam Grunstein, Petrus Gunarso, Heru Komarudin, Omar Masera, Andrew Miccolis, Krystof Obidzinski and Sergio Romero. The authors also gratefully acknowledge the intellectual and methodological contributions of Pablo Pacheco and comments from anonymous reviewers.

\section{References cited}

Abramovay, R. 2008 A political-cultural approach to the biofuels market in Brazil. Universidade de Sao Paulo, Sao Paolo, Brazil.

Adnan, H. 2010 Malaysia's biodiesel industry at a standstill. The Star, 6 September. http://biz. thestar.com.my/news/story.asp?sec $=$ business $\% C$ 3\%A3\%C2\%A3\%C3\%A2\%C2\%AF\&file=/2010/9/6/ business/6952930 [2 December 2010].

Andrade, R.M. and Miccolis, A. In press. Analysis of the legal and institutional frameworks for biofuels at national and sub-national levels in Brazil. Working paper. CIFOR, Bogor, Indonesia.

Baskoro, F.M. 2010 Renewable energy producers to get tax breaks. The Jakarta Globe, 16 May. http:// www.thejakartaglobe.com/business/renewableenergy-producers-to-get-tax-breaks/375280 [28 September 2010].

Cámara Nacional de las Industrias Azucarera y Alcoholera 2010 Reactivación de la producción de alcohol en los ingenios azucareros. Mexican Senate. http://www.senado.gob.mx/comisiones/ LX/agroindustriaazucarera/content/eventos/ foro_nacional/Rodriguez_Mendez.pdf [29 September 2010].

Caroko, W., Komarudin, H., Obidzinski, K., and Gunarso, P. In press. Analysis of policy and institutional frameworks for biofuels development in Indonesia. Working paper. CIFOR, Bogor, Indonesia.

Chin, M. In press. Biofuels in Malaysia: analysis of the legal and institutional framework. Working paper. CIFOR, Bogor, Indonesia.
Colitt, R. and Ewing, R. 2010 Brazil curtails land sales to foreigners. Reuters, 24 August. http://www.reuters. com/article/idUSN2425631120100824 [10 November 2010].

Dillon, H.S., Laan, T. and Dillon, H.S. 2008 Biofuel—at what cost? Government support for ethanol and biodiesel in Indonesia. Global Subsidies Initiative of the International Institute for Sustainable Development, Geneva, Switzerland.

German, L.A. and Schoneveld, G.C. In press. Review of the early legal and institutional framework for biofuel investments in Zambia. Working paper. CIFOR, Bogor, Indonesia.

Goldemberg, J., Coelho, S.T., Nastari, P.M. and Lucon, O. 2004 Ethanol learning curve- - the Brazilian experience. Biomass and Bioenergy 26(3): 301-304.

Koh, L.P. and Wilcove, D.S. 2008 Is oil palm agriculture really destroying tropical biodiversity? Conservation Letters 1(2): 60-64.

Romero-Hernández, O., Masera, O., Romero, S. and Miriam Grunstein, M. In press. Analysis of the legal and institutional frameworks for biofuels at national and sub-national levels in Mexico. Working paper. CIFOR, Bogor, Indonesia.

Schifter, I., Díaz, L., Rodríguez, R. and Salazar, L. 2010 Assessment of Mexico's program to use ethanol as transportation fuel: impact of $6 \%$ ethanol-blended fuel on emissions of light-duty gasoline vehicles. Environmental Monitoring and Assessment. doi 10.1007/s10661-010-1391-X.

Schoneveld, G.C. and German, L.A. In press. The effectiveness of the Ghanaian policy, legal, and institutional framework in regulating large-scale land acquisitions for biofuels. Working paper. CIFOR, Bogor, Indonesia.

Sheil, D., Casson, A., Meijaard, E., van Noordwijk, M., Gaskell, J., Sunderland-Groves, J., Wertz, K. and Kanninen, M. 2009 The impacts and opportunities of oil palm in Southeast Asia: what do we know and what do we need to know? Occasional Paper 51. CIFOR, Bogor, Indonesia.

United States Department of Agriculture Foreign Agricultural Service (USDA FAS) 2010 Malaysia: biofuels annual report 2010. GAIN Report No. MY0008. USDA, Kuala Lumpur, Malaysia. http://gain.fas.usda. gov/Recent\%20GAIN\%20Publications/Biofuels\%20 Annual_Kuala\%20Lumpur_Malaysia_7-16-2010.pdf [2 December 2010].

van Gelder, J.W., Bailis, R. and German, L. In press. Global and regional trends and scenarios in bioenergy trade and investment: an analysis of forest-rich countries in Asia, Latin America and Africa. CIFOR, Bogor, Indonesia. 
This report was produced with the financial assistance of the European Union, under the project, 'Bioenergy, sustainability and trade-offs: can we avoid deforestation while promoting bioenergy?' European Community Contribution Agreement EuropeAid/ ENV/2007/143936/TPS.

The project aims to contribute to sustainable bioenergy development that benefits local people in developing countries, minimises negative impacts on local environments and rural livelihoods, and contributes to global climate change mitigation. The project will achieve this by producing and communicating policy-relevant analyses that can inform government, corporate and civil society decision making related to bioenergy development and its effects on forests and livelihoods. The project is managed by CIFOR and implemented in collaboration with the Council on Scientific and Industrial Research, South Africa, Joanneum Research, Austria, the Universidad Autónoma de México, and the Stockholm Environment Institute, Sweden. The views expressed in this brief can in no way be taken to reflect the official opinion of the European Union.
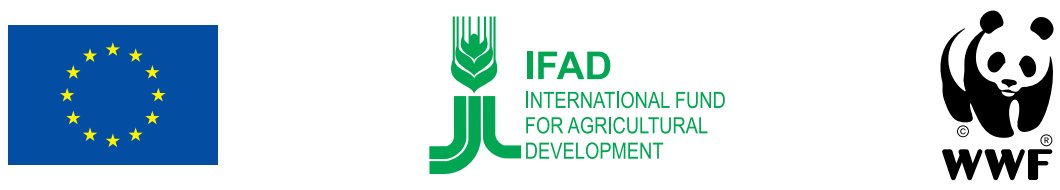

\section{Center for International Forestry Research}

CIFOR advances human wellbeing, environmental conservation and equity by conducting research to inform policies and practices that affect forests in developing countries. CIFOR is one of 15 centres within the Consultative Group on International Agricultural Research (CGIAR). CIFOR's headquarters are in Bogor, Indonesia. It also has offices in Asia, Africa and South America. 